\title{
REVIEW
}

\section{The determination of nitrogen status in microalgae}

\author{
Kevin J. Flynn \\ Dunstaifnage Marine Laboratory, PO Box 3, Oban, Argyll PA34 4AD, Scotland, United Kingdom
}

\begin{abstract}
Present methods used for the determination of $\mathrm{N}$-status in microalgae typically involve testing for the existence of gross metabolic changes which develop in response to N-stress. Such approaches have 2 problems. First, the experimental techniques may be inappropriate for the species present and may perturb the organisms, possibly creating artifacts. Second, these gross changes, such as changes in rates of $\mathrm{CO}_{2}$-fixation and $\mathrm{N}$-source uptake, may be affected by factors other than $\mathrm{N}$-stress. There is a need to develop methods to detect metabolic changes which themselves trigger the genetic response to $\mathrm{N}$-stress rather than to detect the products of that response. Such changes are likely to be in relative proportions of key metabolites of $C$ and $N$ metabolism, as in bacteria. It is suggested that only in the presence of excess $\mathrm{NH}_{4}^{+}$are the processes of cellular response to $\mathrm{N}$-stress fully suppressed. As a consequence, microalgae throughout the oceans may show some symptoms of $\mathrm{N}$-stress. The level of derepression of the $\mathrm{N}$-stress responses which corresponds to growth-limitation, and hence is of ecological significance, needs to be determined.
\end{abstract}

\section{INTRODUCTION}

Understanding mechanisms which control production in the oceans is central to our wider understanding of marine ecology. Nutrient, usually nitrogen, limitation of phototrophic production is frequently suggested. In nature, nutrient limitation is invariably a rate limitation because nutrients are cycled between components of the food web; nitrogen may become limiting only when processes of regeneration are outstripped by demand (see Flynn 1989b). Results from tests for Nstress in microalgae, then, may be useful in attempting to explain ecology and productivity provided that the results and our interpretations of them are reliable.

The aims of this review are to consider the problems associated with methods used in past attempts to determine the $\mathrm{N}$-status of microalgae and, with reference to recent developments, to look towards the future development of more sensitive and reliable methods. Readers who require further information on more general aspects of microalgal $\mathrm{N}$-metabolism should consult Wheeler (1983) and Syrett (1988), and references therein.

Some of the examples given are not marine organisms; they are included because the biochemical basis for responses to nutrient stress are most likely similar while data for marine organisms are incomplete.

\section{CAUSES OF NITROGEN STRESS; C, N, P INTERACTIONS}

$\mathrm{N}$-status is measured on a continuous scale from $\mathrm{N}$ replete (zero stress), through $\mathrm{N}$-sufficiency (enough stress to promote derepression of nitrate transport and assimilation processes, for example, but not enough to be growth limiting), down to $\mathrm{N}$-deplete (maximum stress and no growth). The differences between the $\mathrm{N}$ replete and $\mathrm{N}$-sufficient phases may not be apparent by following growth rates in chemostat cultures. However, the $\mathrm{N}$-replete cells may lay down more $\mathrm{N}$ in storage compounds, and the metabolic state of the cells may differ, with growth rate being limited by another factor (ultimately by genetic/cell cycle factors). By the criteria used in chemostat theory (single parameter variation), determining the level of stress which results in $\mathrm{N}$ limitation of growth should be a simple process. However, in nature few parameters are near constant and because of the multi-variant conditions, which may stress the cells in different ways, simple models such as cell quota approaches (e.g. Droop 1974) are inadequate to describe growth in nature.

Stress may be caused by environmental factors (e.g. the nutrient is absent from the medium, or present at levels at which transport processes are rate limiting) or 
it may be a function of physiology (e.g. nutrient is in such a form that metabolic processes for conversion into other compounds are rate limiting). Physiological $\mathrm{N}$-stress is an important concept which is rarely considered. It seems probable that the occurrence of physiologically induced stress forms the basis for the evolution of, for example, substrate preference for $\mathrm{NH}_{4}^{+}$ over $\mathrm{NO}_{3}^{-}$(but see below).

Interaction between environmental and physiological stress occurs at the level of nutrient transport, especially when 2 or more $\mathrm{N}$-sources are present at different concentrations and require different metabolic processes for their incorporation. Although the rate of transport at the prevailing substrate concentration is more important than comparisons of the half-saturation coefficient $\mathrm{K}_{\mathrm{s}}$ with substrate concentration, substrate concentration may still be a significant limiting factor at 3 to $5 \times \mathrm{K}_{\mathrm{s}}$. Because of the possible interference of metabolic and transport processes (Wheeler et al. 1982, Flynn \& Butler 1986, Harrison et al. 1989), which raises further doubts about the reliability and usefulness of $K_{s}$ values, we cannot be sure how important limitation is at the point of uptake in nature. Clearly, however, in an environment in which nutrients may be supplied in pulses, substrate concentrations will on occasion be rate limiting.

Illumination is subject to variation in both quantity and quality over both short and long time periods in nature. $\mathrm{C}$ or $\mathrm{N}$ status alone can only be described for cultures for which only one variable (photon flux density or nutrient concentration) is present; in nature the two are inextricably linked in $\mathrm{C}-\mathrm{N}$ status. This interaction is complex because, for example, $\mathrm{C}$ and $\mathrm{N}$ are required for the synthesis of the photosynthetic apparatus, while the processes of inorganic $\mathrm{C}$ and $\mathrm{N}$ uptake need not be coupled. The importance of this interaction for $\mathrm{N}$ metabolism has long been known (e.g. Macisaac \& Dugdale 1972).

Amino acid synthesis is one of the first, and arguably the most important, points of interaction between $N$ and $\mathrm{C}$ assimilations. The data in Fig. 1 show the

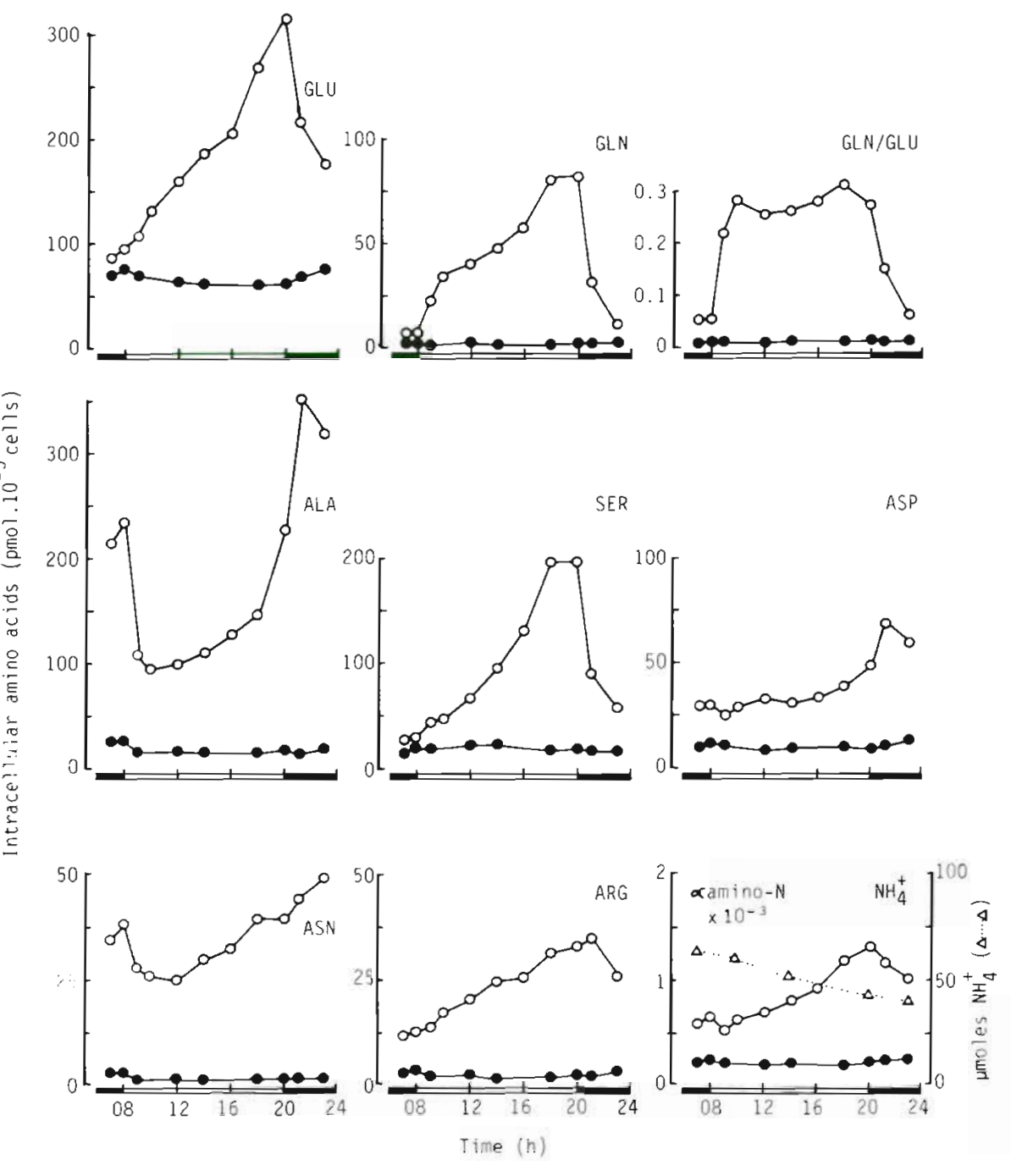

Fig. 1 Dunaliella primolecta Butcher. Changes in concentrations of intracellular amino acids during growth in a $12 \mathrm{~h} / 12 \mathrm{~h}$ light-dark cycle $\left(80\right.$ umol m $\left.{ }^{-2} \mathrm{~s}^{-1}\right)$. (1) Cells were growing in the presence of $\mathrm{NH}_{4}^{+}$(concentrations bottom right; $\quad-1$; or $(\bullet)$ had been resuspended in $\mathrm{N}$-free medium and $\mathrm{N}$-deprived for $2 \mathrm{~d}$. Growth medium, methods of sampling and analysis as described by Flynn \& Fielder (1989). Most cell division occurred between 22:00 and 06:00 h; typical cell densities of 1.5 to $3 \times 10^{4} \mathrm{ml}^{-1}$. Care was taken to prevent accidental illumination of the culture during sampling in the dark phase. GLU: glutamate: GLN: glutamine; ALA: alanine: SER: serine; ASP: aspartate; ASN asparagine; $A R G$ : arginine 
changes in concentrations of intracellular free amino acids occurring in a chlorophyte during growth in a light-dark cycle. The onset of darkness results in a decrease in concentrations of many amino acids, probably as a consequence of continued protein synthesis in darkness (Cuhel et al. 1984) in the absence of significant new amino acid synthesis. The concentrations of amino acids in $\mathrm{N}$-deprived cells are much lower and show less variation over the day. These data illustrate the significance of changes which occur during simple changes in illumination. They also show the potential problems in extrapolating results obtained, and in taking methods developed using continuously illuminated cultures into the real world. Unfortunately, most laboratory experiments have used cultures grown in continuous light both in an attempt to promote more rapid growth and to eliminate the significant fluctuations, such as those shown in Fig. 1, caused by changes in light and dark.

The effects of darkness or inadequate illumination can be divided into C-stress and energy-stress. There may be a specific requirement for photosynthesis to supply C-skeletons of some amino acids, whilst processes of ammonium incorporation into amino acids and the subsequent transamination processes require ATP and/or $\mathrm{NAD}(\mathrm{P}) \mathrm{H}$. The preliminary processes of $\mathrm{N}_{2}$ fixation or $\mathrm{NO}_{3}^{-}$reduction, where applicable, make heavy demands for reductant which must be supplied either directly or indirectly from photosynthesis. Flynn \& Gallon (1989) suggest that $\mathrm{N}_{2}$-fixing non-heterocystous cyanobacteria are physiologically $\mathrm{N}$-stressed.

Another problem stems from the use of measurements of C-fixation to estimate production (Flynn 1988a). The question of nutrient limited algal production often translates to a question of nutrient limitation of $\mathrm{CO}_{2}$-fixation. The answers to these questions need not be the same if a heterotrophic potential is being realized. The ultimate function of a microalga is to reproduce and not to fix $\mathrm{CO}_{2}$ for the benefit of the food chain. However, as rates of $\mathrm{CO}_{2}$-fixation are of undoubted importance to the total ecosystem, the methods used for the determination of N-status may need to be chosen depending on the type of question being asked.

P-limitation in the oceans is usually considered less common than N-limitation (Goldman et al. 1979, Smith 1984, Smith et al. 1986). Even when levels of inorganic $\mathrm{P}$ are very low, P-stress may be reduced by the use of polyphosphate reserves maintained by many algae. The detection of alkaline phosphatase activity is often used to detect P-stress, yet by the time that this activity appears the cells may be suffering severe P-deprivation (see Flynn et al, 1986). Because of the role that $P$ plays in cell energetics, P-stress could affect many reactions of C and $\mathrm{N}$ metabolism. Terry et al. (1985) report that P- deprivation severely restricts the ability to store $\mathrm{N}$ in non-protein forms, presumably affecting amino acid synthesis. Davies \& Sleep (1989) review the interaction of P-stress with $\mathrm{CO}_{2}$-fixation and $\mathrm{N}$ uptake, an important, though neglected, area of nutrient physiology.

\section{PAST METHODS USED FOR THE DETECTION OF N-STRESS IN MICROALGAE}

When $\mathrm{N}$-stress is induced in laboratory cultures, many metabolic changes occur. There is not an immediate 'shutting down' of metabolic processes, rather a redirection of the cell's activity. Thus transport proteins for alternative N-sources (Syrett et al. 1986), and enzymes for the assimilation of those sources (such as nitrate reductase), may be synthesized or derepressed (Hipkin \& Syrett 1977, Everest et al. 1986, Syrett \& Peplinska 1988). Methods used for the detection of $\mathrm{N}$ stress often rely on detecting the occurrence of such changes (Tables 1 and 2). Works in which different criteria for the determination of $\mathrm{N}$-status have been compared include Vincent (1981), Chiaudani \& Vighi (1982), Glibert \& McCarthy (1984), Dortch et al. (1985) and Paasche \& Erga (1988).

Methods requiring incubation of organisms usually involve the addition of the suspected limiting nutrient and monitoring any change in growth or metabolism (Table 1). Although increase in growth (Table 1a) appears the ideal parameter to monitor, the prolonged incubation required is to be avoided because of the risks associated with containment (stress and selective pressures for different organisms). Enhanced ${ }^{14} \mathrm{CO}_{2}$ fixation following $24 \mathrm{~h}$ incubation with a test nutrient (Table $1 \mathrm{~b}$ ) is an alternative to measuring growth rate changes; short-term incubations may produce misleading conclusions (Goldman \& Dennett 1983). Measurements of protein synthesis, a direct function of growth, may offer a more attractive alternative but even this requires incubations exceeding $3 \mathrm{~h}$ (Lohrenz \& Taylor 1987).

Tests of enhancement of dark ${ }^{14} \mathrm{CO}_{2}$ uptake following addition of, typically, $\mathrm{NH}_{4}^{+}$(Table 1c) only work well at extremes of high and low N-status, but the improved method comparing the enhancement in darkness and light $\left(V_{D}: V_{L}\right.$; Table $\left.1 d\right)$ which can give information on the degree of stress is, not surprisingly, sensitive to changes in illumination during the incubation (Glibert et al. 1985). The alternatives, tests of $\mathrm{N}$ source uptake rates and fate (Table 1e to i) offer little advantage except where specific information is required on the effects of perturbation with alternative $\mathrm{N}$-sources. The use of ${ }^{15} \mathrm{~N}$ analogues has its own problems. ${ }^{15} \mathrm{~N}$ methods are not tracer studies and one may question what effects the addition of relatively high 
Table 1. Some criteria used for the diagnosis of $\mathrm{N}$-limitation of microalgal growth requiring incubations of samples. Organisms: LC, laboratory cultures or NP, natural populations; bac, Bacillariophyceae (Chrysophyta); chl, Chlorophyceae (Chlorophyta); cry, Cryptophyta; cya, Cyanophyta; pra, Prasinophyceae (Chlorophyta); pry, Prymnesiophyceae (Chrysophyta); pyr, Pyrrhophyta; var, various or unspecified. Sources are not exhaustive

\begin{tabular}{|c|c|c|c|}
\hline Criterion & Organism & Comments & Source \\
\hline $\begin{array}{l}\text { (a) Enhanced growth } \\
\text { on enrichment }\end{array}$ & NP (bac/var) & $\begin{array}{l}\text { Incubations of days may cause artifacts criti- } \\
\text { cally reviewed by Hecky \& Kilham (1988) }\end{array}$ & $\begin{array}{l}\text { Menzel et al. (1963), Mae- } \\
\text { strini et al. (1986) }\end{array}$ \\
\hline $\begin{array}{l}\text { (b) Enhanced light } \\
\text { C-fixation on } \\
\text { enrichment }\end{array}$ & NP (var) & Incubation of $24 \mathrm{~h}$ may cause artifacts & Wafer et al. (1988) \\
\hline $\begin{array}{l}\text { (c) Enhanced dark } \\
\text { C uptake on } \\
\text { enrichment }\end{array}$ & $\begin{array}{l}\mathrm{LC}(\mathrm{bac} / \mathrm{chl} / \mathrm{cya}) \\
\mathrm{NP}(\mathrm{bac} / \mathrm{cya} / \mathrm{pyr})\end{array}$ & $\begin{array}{l}\text { Enhancement ratio depends on incubation } \\
\text { period (typicaly } 2 \text { to } 3 \mathrm{~h} \text { ), critical ratio } \pm \\
\text { enrichment }=2 \text { for deprivation, 'all or nothing } \\
\text { indicator' and response differs depending on } \\
\text { growth-N \& test-N. May not work with pro- } \\
\text { karyotes }\end{array}$ & $\begin{array}{l}\text { Yentsch et al. (1977), Vincent } \\
\text { (1981), Goldman \& Dennett } \\
\text { (1983, 1986), Glibert et al. } \\
\text { (1985), Paasche \& Erga } \\
\text { (1988) }\end{array}$ \\
\hline (d) $V_{D}: V_{L}$ & $\begin{array}{l}\text { LC (bac) } \\
\text { NP (var) }\end{array}$ & $\begin{array}{l}\text { Modified dark-C method comparing enhance- } \\
\text { ment in dark and light. Gives degree of depri- } \\
\text { vation but sensitive to light changes during } \\
\text { test }\end{array}$ & $\begin{array}{l}\text { Goldman \& Dennett (1983). } \\
\text { Glibert et al. (1985) }\end{array}$ \\
\hline $\begin{array}{l}\text { (e) Enhanced } \mathrm{NH}_{4}^{+} \\
\text {uptake rate or } \\
\text { capacity }\end{array}$ & $\begin{array}{l}\text { LC (bac/chl/cya/pyr) } \\
\text { NP (cya/bac) }\end{array}$ & $\begin{array}{l}\text { Luxury uptake may not indicate } \mathrm{N} \text {-deprivation } \\
\text { if cells grown on } \mathrm{NO}_{3}^{-} \text {(see Horrigan \& } \\
\text { McCarthy 1982) }\end{array}$ & $\begin{array}{l}\text { Vincent (1981), Dortch et al. } \\
\text { (1982) }\end{array}$ \\
\hline (f) $V_{\mathrm{SAT}} / V_{\mathrm{TRACE}}$ & NP (var) & $\begin{array}{l}\text { Comparison of uptake rates at different sub- } \\
\text { strate concentrations; } \mathrm{N} \text {-deprived if }>1\end{array}$ & Glibert \& McCarthy (1984) \\
\hline $\begin{array}{l}\text { (g) Degree of } \mathrm{NO}_{3}^{-} \\
\text {dependence }\end{array}$ & NP (var) & $\begin{array}{l}\text { Compare rates of } \mathrm{NO}_{3}^{-} \pm \mathrm{NH}_{4}^{+} \text {uptake, } \\
\text { if } \mathrm{N} \text {-deprived } \mathrm{NH}_{4}^{+} \text {inhibition is less }\end{array}$ & Glibert \& McCarthy (1984) \\
\hline $\begin{array}{l}\text { (h) Decreased L:D } \\
\mathrm{NO}_{3}^{-} \text {uptake }\end{array}$ & NP (bac/pyr) & $\begin{array}{l}\text { If } \mathrm{N} \text {-sufficient, } \mathrm{NO}_{3}^{-} \text {uptake occurs in light, } \\
\text { if } \mathrm{N} \text {-deprived, uptake is less photoperiodic }\end{array}$ & Paasche \& Erga (1988) \\
\hline $\begin{array}{l}\text { (i) Incorporation } \\
\text { of } \mathrm{NH}_{4}^{+} \text {into } \\
\text { macromalecules }\end{array}$ & $\begin{array}{l}\text { LC (bac/pry) } \\
\text { NP (var) }\end{array}$ & $\begin{array}{l}\text { If } \mathrm{N} \text {-deprived, incorporation is quicker. } \\
\text { Level of illumination affects results because } \\
\text { of effect on protein synthesis (TCA insol.) }\end{array}$ & $\begin{array}{l}\text { Wheeler et al. (1982), Glibert } \\
\text { \& McCarthy (1984). Kanda et } \\
\text { al. (1988) }\end{array}$ \\
\hline $\begin{array}{l}\text { (j) Periodicity } \\
\text { of metabolism } \\
\text { in L/D cycle }\end{array}$ & LC (bac) & $\begin{array}{l}\text { Protein synthesis periodic when } \mathrm{N} \text {-deprived } \\
\text { Lipid synthesis periodic when } \mathrm{P} \text {-deprived } \\
\text { Nutrient uptake periodic when light limited }\end{array}$ & Terry et al. (1985) \\
\hline
\end{tabular}

concentrations of ${ }^{15} \mathrm{~N}$ substrates (for which there may also be discrimination between ${ }^{14} \mathrm{~N}$ and ${ }^{15} \mathrm{~N}$ ) have on cell metabolism. Collos (1987) discusses errors in analysis of ${ }^{15} \mathrm{~N}$ data affecting, in particular, several studies in which the simultaneous uptakes of several $\mathrm{N}$-sources have been investigated.

These enhancement tests make use of the changes in coupling of $\mathrm{CO}_{2}$-fixation and $\mathrm{N}$-source uptake, and differences in uptake of $\mathrm{NH}_{4}^{+}$and $\mathrm{NO}_{3}$, which occur when algae are $\mathrm{N}$-stressed. However, different groups of algae may use different metabolic pathways and response times and phasing of uptake and growth may also vary (Collos 1986, Glibert et al. 1986). Dortchet al. (1982) say that $\mathrm{NO}_{3}^{-}$uptake by $\mathrm{N}$-deplete cells cultured under continuous illumination is generally much slower than uptake of $\mathrm{NH}_{4}^{+}$This claim appears to contrast with the increased dependence on $\mathrm{NO}_{3}^{-}$rather than $\mathrm{NH}_{4}^{+}$in $\mathrm{N}$-deprived cells from a natural population reported by Glibert \& McCarthy (1984). Such differ- ences may be due to differences in the levels of $C, N$ or $P$ stress as well as any differences between species.

There are fluctuations in activities of key enzymes of $\mathrm{N}$ and $\mathrm{C}$ metabolism during both diurnal illumination changes and $\mathrm{N}$-deprivation (Eppley et al. 1971 , Wheeler et al. 1983). These are associated with periodic (e.g. diurnal) changes in gross metabolism (Terry et al. 1985, Rainbault \& Mingazzini 1987; Table 1). It is likely that such fluctuations in metabolism, especially if they occur during incubations (see Glibert et al. 1985), will affect the reliability of methods used to determine $\mathrm{N}$ status which require incubations. Clearly there are many inherent problems with any technique requiring the incubation of samples (Flynn 1989a).

Some criteria for the diagnosis of $\mathrm{N}$-limitation which do not require incubation of organisms are listed in Table 2. The detection of low levels of inorganic $N$ (DIN) does not mean that growth of a population of phytoplankton (Goldman et a.l. 1979, McCarthy \& 
Table 2. Some criteria used for the diagnosis of N-limitation of microalgal growth which do not require incubations of cell suspensions. Organisms as in Table 1. Comments in quotes are conclusions drawn by method developers. Sources are not exhaustive

\begin{tabular}{|c|c|c|c|}
\hline Criterion & Organism & Comments & Source \\
\hline (a) DIN & $N P$ & Low concentration indicates $\mathrm{N}$-limitation & $\begin{array}{l}\text { Spoken arguments \& } \\
\text { numerous texts }\end{array}$ \\
\hline (b) DIN/Chl & NP(var) & Low ratio indicates $\mathrm{N}$ - limitation & Furnas \& Mitchel (1986) \\
\hline (c) $\mathrm{C} / \mathrm{N}$ & $\begin{array}{l}\text { LC (bac/chl/pry) } \\
\text { NP (bac/pyr/var) }\end{array}$ & $\begin{array}{l}\text { High ratio indicates } N \text {-limitation } \\
\text { Possible diurnal fluctuations (Lancelot \& Billen } \\
\text { 1985) and interference with detritus }\end{array}$ & $\begin{array}{l}\text { Goldman et al. (1979), } \\
\text { Goldman (1986), Paasche } \\
\text { \& Erga (1988) }\end{array}$ \\
\hline $\begin{array}{l}\text { (d) RNA/DNA } \\
\text { protein/DNA } \\
\text { Enzyme assays } \\
\text { Internal DIN }\end{array}$ & $\begin{array}{l}\text { LC (bac/chl/pry/pyr) } \\
\text { NP (bac/pyr) }\end{array}$ & $\begin{array}{l}\text { 'High ratio indicative of high growth rate' } \\
\text { 'High ratio indicative of high growth rate' } \\
\text { 'Indicate source of } N \text { '; see text } \\
\text { 'Indicate source of } N \text { ' }\end{array}$ & Dortch et al. $(1984,1985)$ \\
\hline (e) Amino-N/protein-N & $\begin{array}{l}\mathrm{LC}(\mathrm{bac} / \mathrm{chl} / \mathrm{pry} / \mathrm{pyr}) \\
\text { NP (bac/pyr) }\end{array}$ & $\begin{array}{l}\text { Low ratio indicates } \mathrm{N} \text {-limitation, } \\
\text { Will also fall on prolonged } \mathrm{C} \text {-deprivation } \\
\text { Important to use one methodology }\end{array}$ & $\begin{array}{l}\text { Dortch et al. }(1984,1985) \\
\text { Clayton et al. }(1988)\end{array}$ \\
\hline $\begin{array}{l}\text { (f) Intracellular free } \\
\text { amino acids }\end{array}$ & LC (bac/chl/cry/pry/pyr) & $\begin{array}{l}\text { 'Metabolic finger print' } \\
\text { Too variable between species of similar } \\
\text { N-status, and too complex to interpret }\end{array}$ & $\begin{array}{l}\text { Admiraal et al. (1986), } \\
\text { Martin-Jézéquel et al. } \\
\text { (1988) }\end{array}$ \\
\hline (g) GLN/GLU & LC (bac/chl/cya/pra/pyr) & Low ratio indicates $\mathrm{N}$-stress - see Table 3 & Flynn et al. (1989) \\
\hline
\end{tabular}

Goldman 1979, Flynn \& Butler 1986, Flynn 1989b) or of macroalgae (Fujita et al. 1989) is N-limited. The organisms may have sufficient N-reserves to survive transient periods of DIN depletion. They may be able to use organic $\mathrm{N}$-sources, or the use and regeneration of nutrients may be so closely coupled that concentrations of DIN in the bulk water column do not rise. Ratios of biological parameters against DIN (Table 2 b) are likely to be of dubious value for the same reasons.

The classic biomarker is the $\mathrm{C} / \mathrm{N}$ ratio (Table $2 \mathrm{c}$ ). Values of $\mathrm{C} / \mathrm{N} / \mathrm{P}$ alter little with growth under different conditions of light and temperature (affecting growth rate), but significantly with changes in nutrient supply (Goldman 1986). Methods of cell collection should be chosen that do not cause cell rupture (Goldman \& Dennett 1985) because the metabolic pool may contribute a significant proportion of $\mathrm{C}$ and $\mathrm{N}$, and because of the nutritional value of prey to predators. The use of flow cytometry (Birkill 1987) to eliminate detritus, and to select particles according to size and shape (criteria possibly used for selection by predators), and pigment, would also be a useful extention

Dortch et al. (1984, 1985) have suggested several indices of general physiological status (Table 2d) which could complement C/N/P data. The detection, or otherwise, of enzyme activities is, however, not a good approach. Problems range from uncertainties of optimal conditions in enzyme assays for different species, to the more complex problems of derepression stimuli. For example, nitrate reductase may be present in cells growing on nitrate and those which have been $N$ deprived, but not in cells growing on high concen- trations of ammonium (Thacker \& Syrett 1972, Rigano \& Violante 1973, Syrett \& Hipkin 1973; but see section below ' $N$-stress and gene regulation').

The problems associated with enhancement techniques (Table $1 b, c, d$ ), attempting to resolve the possibly uncoupled activities of inorganic $\mathrm{C}$ and $\mathrm{N}$ assimilation in conditions of high and low $\mathrm{N}$-status, may be solved by a direct examination of the intracellular pool of metabolites. It is the presence or absence of products of organic synthesis, such as amino acids and $\alpha$-keto acids, which are most likely to be of importance for the genetic regulation of biochemical processes, such as those stimulated when cells are $\mathrm{N}$-deprived. The most simple index of the availability of intracellular free amino acids, a function of $\mathrm{C}-\mathrm{N}$ status, is the ratio of amino-N/protein-N (Dortch et al. 1984, 1985; Table 2e). It is important that the methods used for amino- $\mathrm{N}$ and protein determinations are standardized because the fluctuations in results which may be caused by the use of different assays (Clayton et al. 1988) complicate comparisons of data (compare data and methods of Dortch et al. 1985 with Martin-Jézéquel et al. 1988). The value of amino- $\mathrm{N} /$ protein- $\mathrm{N}$ may be unaffected by $\mathrm{N}$-source use so that the nutrient status of cells growing on organic- $\mathrm{N}$, which may not stimulate $\mathrm{CO}_{2}$-fixation (Flynn \& Butler 1986), will also be indicated.

More specifically one could examine the composition of the amino acid pool, using it as a metabolic fingerprint' (Admiraal et al. 1986; Table 2f). The problem here is that interspecific differences appear to equal or exceed intraspecific differences caused during $\mathrm{N}$ deprivation (Martin-Jézéquel et al. 1988) which would 
complicate the interpretation of data obtained from field collections of mixed populations. Furthermore, significant changes in levels of individual amino acids can occur during a light-dark cycle (Fig. 1) when the availability of extracellular $\mathrm{N}$ does not alter.

Of the 20 or so amino acids commonly analysed. only a few are of universal importance in both quantity and quality. The most important of these are glutamate (GLU) and glutamine (GLN). GLU and GLN play central roles in the initial incorporation of intracellular ammonium and in the synthesis of other amino acids, nucleic acids and derivatives. The relative proportions of GLN and GLU appear of use in assessing C-N status (Tables $2 \mathrm{~g}$ and 3).

\section{GLN/GLU}

The incorporation of ammonium occurs mainly either through the action of glutamic dehydrogenase (GDH) or glutamine synthetase + glutamine-oxoglutarate aminotransferase (GS-GOGAT). The latter is considered to be more important when the $\mathrm{N}$-source is at low concentration because substrate affinity is higher, although energy demands are greater. Clayton \& Ahmed (1986, 1988), Ahmed \& Hellebust (1988) and Syrett \& Peplinska (1988) provide information on the assay of these enzymes. Ahmed \& Hellebust (1988) suggest that GS-GOGAT is the major entry point for the assimilation of intracellular $\mathrm{NH}_{4}^{+}$in microalgae. Experiments in which GLU decreases while GLN increases immediately following addition of $\mathrm{NH}_{4}^{-}$to $\mathrm{N}$ stressed cells (Turpin \& Harrison 1978, Flynn et al. 1989, Flynn \& Hipkin 1990) also suggest a key role for GS. By GS-GOGAT, the levels of GLN, GLU and 2oxoglutarate (2OG) are closely coupled:

$$
\mathrm{NH}_{4}^{+}+\mathrm{GLU} \rightarrow \mathrm{GLN}_{i} \mathrm{GLN}+2 \mathrm{OG} \rightarrow 2 \mathrm{GLU}
$$

The ratio GLN/GLU becomes high ( $>0.5$ ) when the supply of $\mathrm{C}$ (specifically $20 \mathrm{G}$ ) is rate limiting (Flynn et al. 1989) provided that reductant and ATP are nonlimiting. This could occur either in darkness (but see below) or conceivably in light when levels of $\mathrm{CO}_{2}$ (aq) become limiting (for coccolithophorids, for example, which cannot use $\mathrm{HCO}_{3}^{-}$; Sikes \& Wheeler 1982). GLN/ GLU is low $(<0.1)$ when either environmental $N$-stress (absence of $\mathrm{N}$-source from medium) or physiological $\mathrm{N}$ stress (absence of adequate reductant for example) occurs resulting in a shortfall in intracellular $\mathrm{NH}_{4}^{+}$. Short-term incubations (5 to $10 \mathrm{~min}$ ) in darkness with $\mathrm{NH}_{4}^{+}$induce marked changes in GLN/GLU (Flynn et al. 1989) and could be used to help differentiate between environmental and physiological N-stress.

In the yeast Candida nitratophila, $\mathrm{N}$-deprivation results in decreased GLN/GLU and C-deprivation causes increased GLN/GLU (Flynn \& Hipkin 1990). In microalgae, however, photosynthesis may affect the response. When the diatom Phaeodactylum tricornutum is $\mathrm{N}$-deprived in light the ratio falls, when $\mathrm{N}$ deprived in darkness the ratio alters little and when darkened only (C-deprived), the ratio rises (Flynn et al. 1989). In the chlorophytes Tetraselmis marina (Flynn et al. 1989) and Dunaliella primolecta (Fig. 1), the ratio is again low when $\mathrm{N}$-deprived but is also low when the cells are placed in darkness. The implication is that these species use different metabolic pathways for the synthesis of C-skeletons for amino acids and/or for the supply of reductant. Such differences may help to explain why results from the use of enhancement techniques on natural populations have sometimes given inconclusive results (e.g. Paasche \& Erga 1988).

In the data of both Haberstroh \& Ahmed (1986) and Flynn \& Hipkin (1990), there are indications of the extra physiological stress imparted by the utilization of $\mathrm{NO}_{3}^{-}$ rather than $\mathrm{NH}_{4}^{+}$, with levels of GLN/GLU and of concentrations of amino acids in general being slow to respond when $\mathrm{N}$-deplete cells are re-fed with $\mathrm{NO}_{3}^{-}$. Addition of $\mathrm{NO}_{3}^{-}$, but not of $\mathrm{NH}_{4}^{+}$, to $\mathrm{N}$-deprived cells of Chlorella fusca stimulates $\mathrm{O}_{2}$ evolution, the implication being that photogenerated electrons are diverted from $\mathrm{CO}_{2}$ fixation to $\mathrm{NO}_{3}^{-}$reduction (Thomas et al. 1976).

Table 3 gives values of GLN/GLU for a wide range of microalgae grown under different conditions and sampled, extracted and analysed using a range of techniques. The only inconsistent values are those for some of the diatoms tested by Admiraal et al. (1986), although the trend (higher values at higher N-status) is consistent. In contrast with the values of Admiraal et al. (1986), the values for Skeletonema costatum obtained by Haberstroh \& Ahmed (1986) are in agreement with values given by Flynn et al. (1989). Differences may be due to the conditions of illumination at the time of sampling, as for the diatom Phaeodactylum tricornutum GLN/GLU is elevated when C-deprived (Table 3). The data of Rijstenbil \& Sinke (1989) show GLN/GLU increasing with growth rate in $\mathrm{N}$-limited chemostats of $S$. costatum. The data of Martin-Jézéquel et al. (1988) have not been included because it is not clear what the $\mathrm{N}$-status of their cultures was; their data for amino-N/protein- $\mathrm{N}$ from cells reported to be growing in exponential or stationary phase are also not consistent with the reports of Dortch et al. (1984, 1985).

The data for $\mathrm{N}_{2}$-fixing cyanobacteria (Table 3) gives an insight into the advantage of physically separating $\mathrm{N}_{2}$-fixation and $\mathrm{CO}_{2}$-fixation. In the non-heterocystous Gloeothece sp., the conflict of $\mathrm{O}_{2}$ production during photosynthesis and its deactivation of nitrogenase, plus the heavy demand for reductant for $\mathrm{N}_{2}$-fixation within one cell type, appear to conspire to give physiological 
Table 3. Values of the mole ratio of intracellular glutamine/glutamate (GLN/GLU). Cultures have been grown to the $N$-status indicated unless otherwise stated; low $\mathrm{N}$-status typically indicates a period of $\mathrm{N}$-deprivation. Many of the studies were not performed specifically to measure GLN/GLU and the ratios have been calculated from the original data L: continuous illumination; C: chemostat-culture; LD: light-dark cycle

\begin{tabular}{|c|c|c|c|c|c|}
\hline \multirow[t]{3}{*}{ Species } & \multicolumn{3}{|c|}{ GLN/GLU } & \multirow{3}{*}{$\begin{array}{l}\text { Other } \\
\text { conditions } \\
\& \text { comments }\end{array}$} & \multirow[t]{3}{*}{ Source } \\
\hline & \multirow[t]{2}{*}{ Low $\mathrm{N}$-status } & \multicolumn{2}{|c|}{ High N-status } & & \\
\hline & & $\mathrm{NO}_{3}^{-}$ & $\mathrm{NH}_{4}^{+}$ & & \\
\hline \multicolumn{6}{|l|}{ CYANOPHYTA } \\
\hline Anabaena variabilis & 0.10 & - & - & $0.50^{\mathrm{a}} ; L_{i} C^{\mathrm{b}, c}$ & Niven et al. (1987) \\
\hline Gloeothece sp. & 0.05 & - & $0.50^{r}$ & $0.10^{\mathrm{d}}: \mathrm{LD}^{\mathrm{d}}$ & Flynn \& Gallon (1989\} \\
\hline \multicolumn{6}{|l|}{$\begin{array}{l}\text { CHLOROPHYTA } \\
\text { CHLOROPHYCEAE }\end{array}$} \\
\hline Dunaliella primolecta & 0.10 & - & 0.45 & $\mathrm{LD}^{1}$ & Flynn (1990) \\
\hline Nannochloris sp. & 0.05 & - & 0.41 & $L D^{\prime}$ & Flynn (1990) \\
\hline Stichococcus bacillaris & 0.10 & 0.5 & $1.75^{\mathrm{e}, \mathrm{r}}$ & $\mathrm{LD}^{\prime}$ & Flynn et al. (1989) \\
\hline Stichococcus minor & 0.03 & - & 0.54 & $L D^{f}$ & Flynn (1990) \\
\hline \multicolumn{6}{|l|}{ PRASINOPHYCEAE } \\
\hline Mantoniella squamata & 0.05 & 0.40 & $4.0^{\mathrm{er}}$ & $\mathrm{LD}^{\mathrm{I}}$ & Flynn et al. (1989) \\
\hline Omega $48-23$ & 0.06 & - & 0.48 & $\mathrm{LD}^{1}$ & Flynn (1990) \\
\hline Tetraselmis marina & 0.1 & $0.50 / 1.00^{r}$ & - & $\mathrm{L}$ & Al-Amoudi \& Flynn (1989) \\
\hline \multicolumn{6}{|l|}{$\begin{array}{l}\text { CHRYSOPHYTA } \\
\text { BACILLARIOPHYCEAE }\end{array}$} \\
\hline Biddulphia sinensis & 0.47 & 0.91 & - & $\operatorname{LD}^{\mathrm{g}, \mathrm{h}, \mathrm{l}}$ & Admiraal et al. (1986) \\
\hline Chaetoceros decipiens & 0.19 & 0.31 & - & $\mathrm{LD}^{g, h, i}$ & Admiraal et al. (1986) \\
\hline Cosinodiscus granii & 1.27 & 6.84 & - & $\operatorname{LD}^{g, h, 4}$ & Admiraal et al. (1986) \\
\hline Cyclotella criptica & 1.28 & 2.36 & - & LD $^{\text {g.h.i. }}$ & Admiraal et al. (1986) \\
\hline \multirow[t]{2}{*}{ Ditylum brightwellii } & 0.13 & 1.35 & - & LD $^{g, h, i}$ & Admiraal et al. (1986) \\
\hline & 0.10 & - & $0.80^{\mathrm{j}}$ & $\mathrm{LD}^{\mathrm{i}} ; \mathrm{C}$ & Rijstenbil et al. (1989) \\
\hline \multirow[t]{2}{*}{ Phaeodactylum tricornutum } & - & 0.35 & - & L & Lu \& Stephens (1984) \\
\hline & $0.1 / 0.8^{\mathrm{k}}$ & - & $0.6 / 1.4^{\mathrm{k}}$ & L & Flynn et al. (1989) \\
\hline \multirow[t]{2}{*}{ Skeletonema costatum } & 0.86 & 1.11 & - & $\mathrm{LD}^{\mathrm{g}, \mathrm{h}, \mathrm{i}}$ & Admiraal et al. (1986) \\
\hline & 0.11 & $0.24^{\mathrm{r}}$ & $1.14^{r}$ & $\mathrm{~L}^{\mathrm{i}}$ & Haberstroh \& Ahmed (1986) \\
\hline Thalassiosira excentrica & 0.16 & 1.00 & - & $L^{g \cdot h \cdot 1}$ & Admiraal et al. (1986) \\
\hline Thalassiosira pseudonana & 0.13 & 0.55 & - & $L_{;}$C & Zehr et al. (1988) \\
\hline \multicolumn{6}{|l|}{ EUSTIGAMATOPHYCEAE } \\
\hline Ellipsoidion sp. & 0.05 & - & 1.34 & $\mathrm{LD}^{\prime}$ & Flynn (1990) \\
\hline \multicolumn{6}{|l|}{ Nannochloropsis oculata } \\
\hline \multicolumn{6}{|l|}{ PRYMNESIOPHYCEAE } \\
\hline Emiliania huxleyi & 0.15 & - & 0.80 & LD & Flynn (1990) \\
\hline \multicolumn{6}{|l|}{ PYRRHOPHYTA } \\
\hline Gymnodinium simplex & 0.15 & - & $0.60^{r}$ & $L_{i} C$ & Turpin \& Harrison (1978) \\
\hline Oxyrrhis marina & 0.05 & - & - & $0.3^{\mathrm{m}}$ & Flynn \& Fielder (1989) \\
\hline \multicolumn{6}{|l|}{ YEAST } \\
\hline Candida nitratophila & 0.05 & 0.5 & $0.6 / 0.7^{\mathrm{k}}$ & $0.3^{n}$ & Flynn \& Hipkin (1990) \\
\hline \multicolumn{6}{|c|}{ During $\mathrm{N}_{2}$-fixation } \\
\hline${ }^{b}$ Nitrogenase activity most a & d by osmotic sh & $\mathrm{k}-$ low $\mathrm{N}$-st & us value is & of shocked cult & ture \\
\hline "Heterocystous & & & & & \\
\hline d Non-heterocystous & & & & & \\
\hline Re-fed in darkness (else in & & & & & \\
\hline 'Sampled during light phase & & & & & \\
\hline g Sample time unknown, see & & & & & \\
\hline 'Cells grown on 'low initial' & igh initial $\mathrm{NO}_{3}^{-}$ & & & & \\
\hline 'Fluctuations in GLN greate: & & & & & \\
\hline Recovery from $\mathrm{N}$-limited gr & due to osmotic s & ck reducing & rowth rate & & \\
\hline${ }^{k}$ Darkness (algae) or C-depr & (yeast) & & & & \\
\hline${ }^{\mathrm{m}}$ Phagotrophic; ratio depeno & N-status of prey & & & & \\
\hline${ }^{n} \mathrm{NH}_{4}^{+}+$amino- $\mathrm{N}$ & 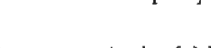 & & & & \\
\hline 'Re-fed (spiked) with $\mathrm{N}$-sour & I a period of $N$ & privation & & & \\
\hline
\end{tabular}


$\mathrm{N}$-stress. This is relieved on addition of $\mathrm{NH}_{4}^{+}$when a typical response to $\mathrm{N}$-pulsing of $\mathrm{N}$-deprived cells is observed (Flynn \& Gallon 1989).

\section{N-STRESS AND GENE REGULATION}

In the bacterium Escherichia coli the intracellular proportions of $20 \mathrm{OG}$ and GLN have been identified as having a key role in gene regulation of metabolic changes in response to $\mathrm{N}$-stress (Magasanik 1988). On increased $N$-stress the low ratio GLN/2OG leads to a lack of signal transducer $P_{11}$ because $20 G$ activates uridylylation of $P_{I I}$ to $P_{I I}(U M P)_{4}$. The lack of $P_{I I}$ allows the phosphorylation of an effector which, through a feedback loop, eventually leads to activation of $\mathrm{N}$-regulated promoters. The lack of $\mathrm{P}_{I I}$ also promotes deadenylylation of GS(AMP) $)_{12}$ to the active enzyme glutamine synthethase (GS). Phosphorylation plays an important role in this regulatory system so that P-stress could be expected to affect responses to $\mathrm{N}$-stress. In Rhizobium leguminosarum, the isoenzymes of $\mathrm{GS}, \mathrm{GS}_{\mathrm{I}}$ and $\mathrm{GS}_{\mathrm{II}}$, are subject to post- and pretranscriptional control respectively (Rossi et al. 1989). GS is reversibly adenylylated as in E. coli and concentrations alter little. GS $\mathrm{I}_{11}$, however, is almost absent in cells grown on $\mathrm{NH}_{4}^{+}$but present at very high levels in cells grown on $\mathrm{NO}_{3}^{-}$and GLU. By such mechanisms a cell has both coarse and fine controls over its $\mathrm{N}$-metabolism. It may be concluded that only at the extreme of growth on excess $\mathrm{NH}_{4}^{+}$can cells be considered to be fully $\mathrm{N}$-replete and that any conditions which result in the derepression/activation of other activities are stages of greater or lesser $\mathrm{N}$-stress.

In comparison with our knowledge of bacterial systems, knowledge of eukaryote regulation of $\mathrm{C}$ and $\mathrm{N}$ metabolism is minimal. Nonetheless, the responses to $\mathrm{N}$-stress, increased GS activity, increased ability to transport different $\mathrm{N}$-sources and decreased GLN/2OG (if one accepts that if $\mathrm{C}$ is not limiting GLN/GLU gives an index of GLN/2OG), do appear similar. Akimova et al. $(1976,1977)$ suggest that in Chlorella pyrenoidosa deactivation of GS may be mediated by GLN and that ADP and AMP inhibit GS activity. Fig. 2 shows how GS activity and GLN/GLU varies in Nannochloropsis oculata grown to different $\mathrm{N}$-status. The implication of this preliminary data, taken with existing knowledge of algal responses to $\mathrm{N}$-stress and growth on different $\mathrm{N}$ sources, is that (as in bacteria) only during growth with excess $\mathrm{NH}_{4}^{+}$(mid to high $\mu \mathrm{M}$ range) are cells NOT Nstressed to some extent. The increased energy requirement for the operation of GS-GOGAT as compared with GDH is available in $\mathrm{N}$-stressed cells which, by definition, have an excess of $\mathrm{C}$ available for respiration.

In cells grown on $\mathrm{NO}_{3}^{-}$, the responses to $\mathrm{N}$-stress are already partly derepressed, hence the rapid uptake of

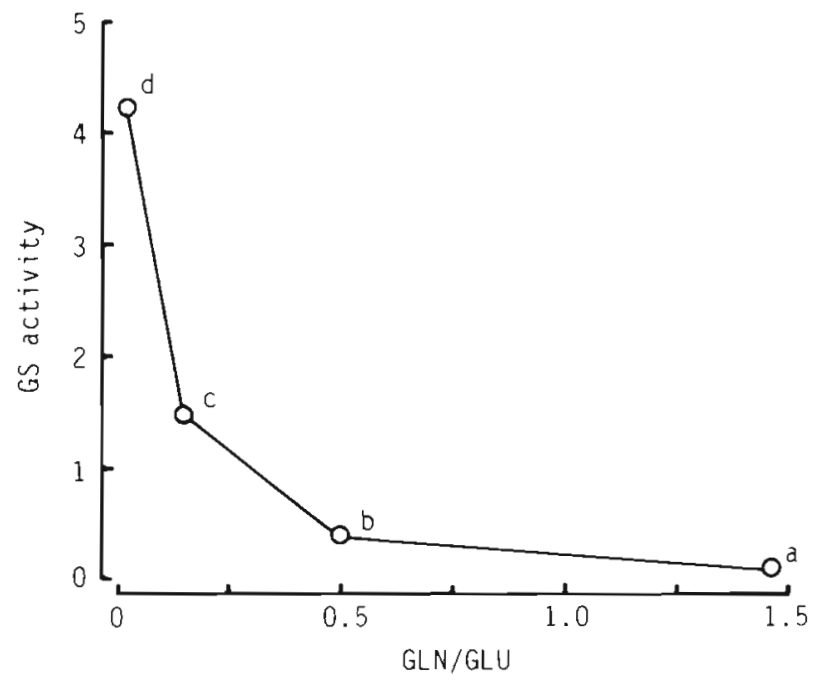

Fig. 2. Suggested relationship between glutamine synthetase (GS) activity and GLN/GLU. Nannochloropsis oculata Hibberd was sampled during growth in conditions described by Everest et al. (1986), under continuous illumination (10 $\mu \mathrm{mol}$ $\mathrm{m}^{-2} \mathrm{~s}^{-1}$ ), in the presence of ammonium (a) or nitrate (b), during $\mathrm{N}$-deprivation (c) and after $2 \mathrm{~d} \mathrm{~N}$-deprivation (d). GS transferase activity (nmol glutamyl hydroxamate $\min ^{-1} 10$ cell) was assayed as described by Syrett \& Peplinska (1988) and intracellular amino acids analysed as described by Flynn (1988b). Cell densities were typically 1 to $2 \times 10^{7} \mathrm{ml}^{-1}$ Given a constant supply of $C$ (i.e. constant illumination), GLN/GLU correlates with GLN/2-oxoglutarate and is an index of $\mathrm{N}$ stress; $\mathrm{N}$-stress increases right to left but does not become growth limiting until between nitrate grown (b) and (c). It is suggested that a similar regulatory system to that in Escherichia coli (Magasanik 1988), in which GLN/2-oxoglutarate regulates GS activity, may operate in microalgae (see text)

$\mathrm{NH}_{4}^{+}$by $\mathrm{NO}_{3}^{-}$-grown cells (e.g. Horrigan \& McCarthy 1982). However, such stress is not often growth limiting and $\mathrm{C} / \mathrm{N}$ ratios of $\mathrm{NH}_{4}^{+}$and $\mathrm{NO}_{3}^{-}$grown cells are not significantly dissimilar. This concept of a sliding scale of $\mathrm{N}$-stress, and more importantly of a sliding scale of the derepression of a cells response to $\mathrm{N}$-stress, also helps to explain the incorporation of $\mathrm{NO}_{3}^{-}$by cells grown in $\mathrm{NH}_{4}^{+}$-limiting culture (Zehr et al. 1989). Likewise it may offer an explanation for the conflict between the 'inhibition' of $\mathrm{NH}_{4}^{+}$uptake by $\mathrm{NO}_{3}^{-}$ reported by Collos (1989) and Collos et al. (1989), using substrate concentrations of $50 \mu \mathrm{M}$, and the inhibition of $\mathrm{NO}_{3}^{-}$uptake by $\mathrm{NH}_{4}^{+}$reported by, for example, Cresswell \& Syrett (1979) who used substrate concentrations in the $\mathrm{mM}$ range. At high (unnatural) concentrations of $\mathrm{NH}_{4}^{+}$, repression of nitrate transport and assimilatory processes becomes complete, whilst at lower concentrations progressive derepression results in an increased ability to use other $\mathrm{N}$-sources. The substrate concentrations at which derepression becomes significant most probably varies between species and groups of microalgae. 


\section{CONCLUSIONS}

Many studies of algal physiology have examined the effects of, and responses to, N-deprivation and refeeding. A major problem has been that there has been no independent measure of $\mathrm{C}-\mathrm{N}$ status with which to compare cultures used in different studies, yet it is clear that $\mathrm{C}-\mathrm{N}$ status of cells can vary significantly with conditions of illumination and quantity and quality of $\mathrm{N}$-source. If we cannot manage to resolve these problems in cultures of known species composition and known nutrient history then how sure can we be of results from field studies? A problem common to most (all?) methods used at present to diagnose $\mathrm{N}$-deprivation is that we measure a symptom of stress and attempt to relate it to growth limitation (the factor which we are usually actually interested in). Yet, often that test criterion may be affected by stress other than $\mathrm{N}$-stress. If we only knew how the gene regulation of microalgal responses to $N$-stress functioned then we would undoubtedly have a better idea of the parameters that we should endeavour to measure when attempting to determine $\mathrm{N}$-stress in natural populations.

The proportions of GLN/GLU appear to correlate well with $\mathrm{C}-\mathrm{N}$ status (Table 3), at least giving an independent measure of $\mathrm{C}-\mathrm{N}$ status in the light phase of growth with which to compare cultures grown under different conditions of photon flux density and substrate type and concentration. However, the proportions of these amino acids are unlikely to be used in gene regulation of the response to $N$-stress because GLN/GLU may fall either due to environmental $N$ stress or to darkness (Fig. 1). The ratio GLN/2OG may not fall significantly, if at all, under these conditions because levels of both $20 \mathrm{G}$ and GLN would fall. The usefulness of GLN/2OG as a monitor of C-N status is unknown at present. There are, however, 2 potential problems; 2-oxoglutarate is extremely unstable in solution and, as it plays such a vital role in many biochemical reactions, the high turnover rate may also make reproducible sampling difficult. A second analysis would also be required, whereas at least measurements of GLN/GLU can be obtained using one simple and sensitive method (Flynn et al. 1989).

There is a clear need for more information on $\mathrm{C}-\mathrm{N}$ biochemistry and gene regulation in microalgae (especially of groups other than chlorophytes and diatoms, such as prymnesiophytes and eukaryotic and prokaryotic picoplankters). With such data new methods for the study of N-stress, and of physiological ecology in general, can be developed. By the use of techniques from molecular biology or of short-term incubation methods (say of less than 10 min duration) in which changes in concentration of key metabolites (those likely to be sources of regulatory signals for gene regulation in specific groups of organisms) are measured in the presence or absence of enrichment, we may also be able to resolve the $\mathrm{C}-\mathrm{N}$ status of components of microbial loop communities. It is essential that all studies be performed using cultures grown under conditions of light and dark simulating those in nature and consider such factors as cumulative stress, caused by P-stress for example, on an organism's response to $\mathrm{N}$-stress.

Acknowledgements. This work was supported by a grant from the Natural Environment Research Council. R. Lewin kindly supplied some of the cultures used in this study. N. Amleh provided the GS data and samples for GLN/GLU analysis presented in Fig. 2. I thank the referees of an earlier version of the work for their useful criticisms.

\section{LITERATURE CITED}

Admiraal, W., Peletier, H., Laane, R. W. P. M. (1986). Nitrogen metabolism of marine planktonic diatoms; excretion, assimilation and cellular pools of free amino acids in seven species with different cell size. J. exp. mar Biol. Ecol. 98: $241-263$

Ahmed, 1., Hellebust, J. A. (1988). Enzymology of ammonium assimilation in three green flagellates. New Phytol. 109: $415-421$

Akimova, N. I., Evstigneeva, Z. G., Kretovich, V L. (1976) Regulation of glutamine metabolism in Chlorella pyrenoidosa. Regulation of glutamine synthetase activity of Chlorella by amino acids. Biokhimiya 41. 1471-1477

Akimova, N. I., Evstigneeva, Z. G., Kretovich, V L. (1977). Regulation of glutamine metabolism in Chlorella pyrenoidosa. Regulation of the glutamine synthetase activity by components of the adenylic system. Biokhimiya 42: 947-951

Al-Amoudi, O. A., Flynn, K. J. (1989). Effect of nitrate-N incorporation on the composition of the intracellular amino acid pool of $\mathrm{N}$-deprived Tetraselmis marina. $\mathrm{Br}$ Phycol. J. 24: $53-61$

Birkill, P. H. (1987). Analytical flow cytometry and its application to marine microbial ecology. In: Sleigh, M. A. (ed.) Microbes in the sea. Ellis Horwood Ltd., Chichester, p. 139-166

Chiaudani, G., Vighi, M. (1982). Multistep approach to identification of limiting nutrients in northern Adriatic coastal waters. Water Res. 16: 1161-1166

Clayton, J. R., Jr, Dortch, Q., Thoresen, S. S., Ahmed, S. I. (1988). Evaluation of methods for the separation and analysis of proteins and free amino acids in phytoplankton samples. J. Plankton Res. 10: 341-358

Clayton, J. R., Jr, Ahmed, S. I. (1986). Detection of glutamate synthase (GOGAT) activity in phytoplankton: evaluation of cofactors and assay optimization. Mar. Ecol. Prog. Ser. 32: $115-122$

Clayton, J. R., Jr, Ahmed, S. I. (1988). Modified assay procedure for enhanced sensitivity of in vitro glutamine synthetase (GS) activity measurements in marine phytoplankton. Mar. Ecol. Prog. Ser. 36: 177-180

Collos, Y (1986). Time-lag algal growth dynamics: biological constraints on primary production in aquatic environments. Mar Ecol. Prog. Ser. 33: 193-206

Collos, Y. (1987). Calculations of ${ }^{15} \mathrm{~N}$ uptake rates by phytoplankton assimilating one or several nitrogen sources Appl. Radiat. Isotopes 38: 275-282 
Collos, Y. (1989). A linear model of external interactions during uptake of different forms of inorganic nitrogen by microalgae. J. Plankton Res. 11: 521-533

Collos, Y., Maestrini, S. Y., Robert, J.-M. (1989). High longterm nitrate uptake by oyster-pond microalgae in the presence of high ammonium concentrations. Limnol. Oceanogr. 34: 957-964

Cresswell, R. C., Syrett, P. J. (1979). Ammonium inhibition of nitrate uptake by the diatom, Phaeodactylum tricornutum. Plant Sci. Lett. 14: 321-325

Cuhel, R. L., Ortner, P. B., Lean, D. R. S. (1984). Night synthesis of protein by algae. Limnol. Oceanogr 29: 731-744

Davies, A. G., Sleep, J. A. (1989). The photosynthetic response of nutrient-depleted dilute cultures of Skeletonema costatum to pulses of ammonium and nitrate; the importance of phosphate. J. Plankton Res. 11. 141-164

Dortch, Q. Clayton, J. R., Jr, Thoresen, S. S., Bressler, S. L., Ahmed, S. I. (1982). Response of marine phytoplankton to nitrogen deficiency: decreased nitrate uptake vs enhanced ammonium uptake. Mar. Biol. 70: 13-19

Dortch, Q., Clayton, J. R., Jr, Thoresen, S. S., Ahmed, S. I. (1984). Species differences in accumulation of nitrogen pools in phytoplankton. Mar. Biol. 81: 237-250

Dortch, Q., Clayton, J. R., Jr, Thoresen, S. S., Cleveland, J. S., Bressler, S. L., Ahmed, S. I. (1985). Nitrogen storage and use of biochemical indices to assess nitrogen deficiency and growth rate in natural plankton populations. J. mar. Res. 43: 437-464

Droop, M. R. (1974). The nutrient status of algal cells in continuous culture. J. mar biol. Ass. U.K. 54: 825-855

Eppley, R. W., Rogers, J. N., McCarthy, J. J., Sourina, A. (1971). Light/dark periodicity in nitrogen assimilation of the marine phytoplankters Skeletonema costatum and Coccolithus huxleyi in N-limited chemostat culture. J. Phycol. 7. 150-154

Everest, S. A., Hipkin, C. R., Syrett, P. J. (1986). Enzyme activities in some marine phytoplankters and the effect of nitrogen limitation on nitrogen and carbon metabolism in Chlorella stigmatophora. Mar. Biol. 90: 165-172

Flynn, K. J. (1988a). The concept of 'primary production' in aquatic ecology. Limnol. Oceanogr. 33: 1215-1216

Flynn, K. J. (1988b). Some practical aspects of measurements of dissolved free amino acids in natural waters and within microalgae by the use of HPLC. Chem. Ecol. 3: 269-293

Flynn, K. J. (1989a). Nutrient limitation of marine microbial production: fact or artefact? Chem. Ecol. 4: 1-13

Flynn, K. J. (1989b). Interaction between nutrient and predator limitation of production in the marine euphotic zone. Chem. Ecol $4: 21-36$

Flynn, K. J. (1990). Composition of intracellular and extracellular pools of amino acids, and amino acid utilization of microalgae of different sizes. J exp. mar. Biol. EcoI (i.n press)

Flynn, K. J., Butler, I. (1986). Nitrogen sources for the growth of marine microalgae: role of dissolved tree amino acids. Mar Ecol. Prog. Ser 34: 281-304

Flynn, K. J., Dickson, D. M. J., Al-Amoudi, O. A. (1989). The ratio of glutamine: glutamate in microalgae: a biomarker for $\mathrm{N}$-status suitable for use at natural cell densities. J Plankton Res. 11: 165-170

Flymn, K. J., Fielder, J. (1989). Changes in intracellular and extracellular amino acids during the predation of the chlorophyte Dunaliella primolecta by the heterntrophic dinoflagellate Oxyrrhis marina and the use of the glutamine/glutamate ratio as an indicator of nutrient status in mixed populations. Mar. Ecol. Prog. Ser. 53: 117-127

Flynn, K. J., Gallon, J. R. (1989). Fluctuations in the intracellu- lar amino acids of Gloeothece during nitrogen fixation and following addition of ammonium. Biochem. Soc. Trans. 17 925-926

Flynn, K. J., Hipkin, C. R. (1990). Changes in intracellular amino acids and glutamine:glutamate during $\mathrm{N}$-deprivation and refeeding in Candida nitratophila. New Phytol. (in press)

Flynn, K. J., Öpik, H., Syrett, P. J. (1986). Localization of the alkaline phosphatase and 5 '-nucleotidase activities of the diatom Phaeodactylum tricornutum. J. gen. Microbiol. 132 189-198

Fujita, R. M., Wheeler, P. A., Edwards, R. L. (1989). Assessment of macroalgal nitrogen limitation in a seasonal upwelling region. Mar. Ecol. Prog. Ser. 53: 293-303

Furnas, M. J., Mitchel, A. W. (1986). Phytoplankton dynamics in the central Great Barrier Reef - I. Seasonal changes in biomass and community structure and their relation to intrusive activity. Cont. Shelf Res. 6: 363-384

Glibert, P. M., Dennett, M. R. Goldman, J. C. (1985). Inorganic carbon uptake by phytoplankton in Vineyard Sound Massachusetts. II. Comparative primary productivity and nutritional status of winter and summer assemblages. $\mathrm{J}$ exp. mar. Biol. Ecol. 86; 101-118

Glibert, P. M., Kana, T M., Olson, R. J., Kirchman, D. L. Alberte, R. S. (1986). Clonal comparison of growth and photosynthetic responses to nitrogen availability in marine Synechococcus spp. J. exp. mar. Biol. Ecol. 101: 199-208

Glibert, P. M., McCarthy, J. J. (1984). Uptake and assimilation of ammonium and nitrate by phytoplankton: indices of nutritional status for natural assemblages. J. Plankton Res. 6: $677-697$

Goldman, J. C. (1986). On phytoplankton growth rates and particulate C:N:P ratios at low light. Limnol. Oceanogr 31. 1358-1363

Goldman, J. C., Dennett, M. R. (1983). Effect of nitrogen source on short-term light and dark $\mathrm{CO}_{2}$ uptake by a marine diatom. Mar. Biol. 76: 7-15

Goldman, J. C., Dennett, M. R. (1985). Susceptibility of some marine phytoplankton species to cell breakage during filtration and post-filtration rinsing. J. exp. mar. Biol Ecol. 86: $47-58$

Goldman, J. C., Dennett, M. R. (1986). Dark $\mathrm{CO}_{2}$ uptake by the diatom Chaetoceros simplex in response to nitrogen pulsing. Mar. Biol. 90: 493-500

Goldman, J. C., McCarthy, J. J., Peavey, D. G. (1979). Growth rate influence on the chemical composition of phytoplank ton in oceanic waters. Nature, Lond. 279: 210-215

Haberstroh, P. R., Ahmed, S. I. (1986). Resolution by high pressure liquid chromatography of intracellular and extracellular free amino acids of a nitrogen deficient marine diatom, Skeletonema costatum (Grev.) Cleve. pulsed with nitrate or ammonium. J. exp. mar. Biol. Ecol. 101. 101-117

Harrison, P. J., Parslow, J. S., Conway, H. L. (1989). Determination of nutrient uptake kinetic parameters: a comparison of methods. Mar Ecol. Prog. Ser. 52: 301-312

Hecky, R. E. Kilham, P. (1988). Nutrient limitation of phytoplankton in freshwater and marine environments: a review of recent evidence on the effects of enrichment. Limnol. Oceanogr. 33: 796-822

Hipkin, C. R., Syrett, P. J. (1977). Some effects of nitrogenstarvation on nitrogen and carbohydrate metabolism in Ankistrodesmus braunii. Planta 133: 209-214

Horrigan, S. G., McCarthy, J. J. (1982), Phytoplankton uptake of ammonium and ured during growth on oxidized forms of nitrogen. J. Plankton Res. 4: 379-390

Kanda, J., Saino, T., Hattore, A. (1988). Nitrogen nutrition and physiological state of natural populations of phytoplankton 
in surface waters of the western Pacific Ocean. Limnol Oceanogr 33: 1580-1585

Lancelot, C., Billen, G. (1985). Carbon-nitrogen relationships in nutrient metabolism of coastal marine ecosystems. Adv. aquat. Microbiol. 3: 263-321

Lohrenz, S. E. Taylor, C. D. (1987). Primary production of protein: I. Comparison of net cellular carbon and protein synthesis with ${ }^{14} \mathrm{C}$-derived rate estimates in a steady-state cultures of marine phytoplankton. Mar. Ecol. Prog. Ser. 35: 277-292

Lu, M. Stephens, G. C. (1984). Demonstration of net influx of free amino acids in Phaeodactylum tricornutum using high performance liquid chromatography. J. Phycol. 20: $584-589$

MacIsaac, J. J., Dugdale, R. C. (1972). Interactions of light and inorganic nitrogen in controlling nitrogen uptake in the sea. Deep Sea Res. 19: 209-232

Maestrini, S. Y., Rochet, M., Legendre, L., Demers, S. (1986) Nutrient limitation of the bottom-ice microalgal biomass (southeastern Hudson Bay, Canadian Arctic). Limnol. Oceanogr. 31: 969-982

Magasanik, B. (1988). Reversible phosphorylation of an enhancer binding protein regulates the transcription of bacterial nitrogen utilization genes. Trends Biochem. Sci. 13: $475-479$

Martin-Jézéquel, V., Poulet, S. A., Harris, R. P., Moal, J., Sumain, J. F. (1988). Interspecific and intraspecific composition and variation of free amino acids in marine phytoplankton. Mar. Ecol. Prog. Ser. 44: 303-313

McCarthy, J. J., Goldman, J. C. (1979). Nitrogenous nutrition of marine phytoplankton in nutrient-depleted waters. Science 203: 670-672

Menzel, D. W., Hulburt, E. M., Ryther, J. H. (1963). The effects of enriching Sargasso Sea water on the production and species composition of the phytoplankton. Deep Sea Res. 10: 209-219

Niven, G. W., Kerby, N. W., Rowell, P., Reed, R. H., Stewart, W. D. P. (1987). The effects of salt on nitrogen-fixation and ammonium assimilation in Anabaena variabilis. Br. Phycol. J. 22: 411-416

Paasche, E., Erga, S. R. (1988). Phosphorus and nitrogen limitation of phytoplankton in the inner Oslofjord (Norway). Sarsia 73: 229-243

Rainbault, P., Mingazzini, M. (1987). Diumal variations of intracellular nitrate storage by marine diatoms: effect of nutritional state. J. exp. mar. Biol. Ecol. 112: 217-232

Rigano, C., Violante, U. (1973). Effect of nitrate, ammonia and nitrogen starvation on the regulation of nitrate reductase in Cyanidium caldarium. Arch. Mikrobiol. 90: 27-33

Rijstenbil, J. W. Sinke, J. J. (1989). The influence of salinity fluctuation on the ammonium metabolism of the marine diatom Skeletonema costatum grown in continuous culture. J. Plankton Res. 11: 297-315

Rijstenbil, J. W., Wijnholds, J. A., Sinke, J. J. (1989). Implications of salinity fluctuations for growth and nitrogen metabolism of the marine diatom Ditylum brightwellii in comparison with Skeletonema costatum. Mar. Biol. 101: 131-141

Rossi, M., Defez, R., Chiuazzi, M., Lamberti, A., Fuggi, A., Iaccarino, M. (1989). Regulation of glutamine synthetase isoenzymes in Rhizobium leguminosarum biovar viceae. J. gen. Microbiol. 135: 629-637

Sikes, C. S., Wheeler, A. P. (1982). Carbonic anhydrase and carbon fixation in coccilithophorids. J. Phycol. 18: 423-426
Smith, S. V (1984). Phosphorus versus nitrogen limitation in the marine environment. Limnol. Oceanogr. 29: 1149-1160

Smith, S. V., Kimmerer, W J., Walsh, T W. (1986). Vertical flux and biogeochemical turnover regulate nutrient limitation of net organic production in the north Pacific gyre. Limnol. Oceanogr. 31. 161-167

Syrett, P. J. (1988). Uptake and utilization of nitrogen compounds. In: Rogers, L. J., Gallon, J. R. (eds.) Biochemistry of the algae and cyanobacteria. Oxford University Press, Oxford, p. 23-39

Syrett, P. J., Flynn, K. J., Molloy, C. J., Dixon, G. K., Peplinska, A. M. Cresswell, R. C. (1986). Effects of nitrogen deprivation on rates of uptake of nitrogenous compounds by the diatom Phaeodactylum tricornutum Bohlin. New Phytol. 101. 39-44

Syrett, P. J., Hipkin, C. R. (1973). The appearance of nitrate reductase activity in nitrogen-starved cells of Ankistrodesmus braunii. Planta 111: 57-64

Syrett, P. J., Peplinska, A. M. (1988). Effects of nitrogendeprivation, and recovery from it, on the metabolism of microalgae. New Phytol. 109: 289-296

Terry, K. L., Hirata, J., Laws, E. A. (1985). Light-, nitrogenand phosphorus-limited growth of Phaeodactylum tricornutum Bohlin strain TFX-1: chemical composition, carbon partitioning and the diel periodicity of physiological processes. J. exp. mar. Biol. Ecol. 86: 85-100

Thacker, A., Syrett, P. J. (1972). The assimilation of nitrate and ammonium by Chlamydomonas reinhardii. New Phytol. 71. $423-433$

Thomas, R. J., Hipkin, C. R., Syrett, P. J. (1976). The interaction of nitrogen assimilation with photosynthesis in nitrogen deficient cells of Chlorella. Planta 133: 9-13

Turpin, D. H., Harrison, P. J. (1978). Fluctuations in free amino acid pools of Gymnodinium simplex (Dinophyceae) in response to ammonia perturbation: evidence for glutamine synthetase pathway. J. Phycol. 14: 461-464

Vincent, W F. (1981). Rapid physiological assays for nutrient demand by the plankton. I. Nitrogen. J. Plankton Res. 3: 685-697

Wafer, M. V. M., Wafer, S., Davassy, V P. (1988). Nitrogenous nutrition and primary production in a tropical oceanic environment. Bull. mar. Sci. 38: 273-284

Wheeler, P. A. (1983). Phytoplankton nitrogen metabolism. In: Carpenter, E. J., Capone, D. G. (eds.) Nitrogen in the marine environment. Academic Press, London, p. 309-346

Wheeler, P. A., Glibert, P. M., McCarthy, J. J. (1982). Ammonium uptake and incorporation by Chesapeake Bay phytoplankton: short term uptake studies. Limnol. Oceanogr 27: 1113-1128

Wheeler, P. A., Olsen, R. J., Chisholm, S. W. (1983). Effects of photocycles and periodic ammonium supply on three marine phytoplankton species. II. Ammonium uptake and assimilation. J. Phycol. 19: 528-533

Yentsch, C. M., Yentsch, C. S., Strube, L. R. (1977). Variations in ammonium enhancement, an indication of nitrogen deficiency in New England coastal phytoplankton populations. J. mar. Res. 35: 537-555

Zehr, J. P., Falkowski, P. G., Fowler, J., Capone, D. G. (1989). Coupling between ammonium uptake and incorporation in a marine diatom: experiments with the short-lived radioisotope ${ }^{13} \mathrm{~N}$. Limnol. Oceanogr. 33: 518-527

Zehr, J. P., Capone, D. G., Falkowski, P. G. (1989). Rapid incorporation of ${ }^{13} \mathrm{NO}_{3}$ by $\mathrm{NH}_{4}$-limited phytoplankton. Mar Ecol. Prog. Ser. 51. 237-241

Manuscript first received: June 26, 1989

Revised version accepted: December 22, 1989 